\title{
GEOGRAPHICAL EXPLORATION OF VEGAN DISHES FROM TURKISH CUISINE
}

\author{
Sibel ÖNÇEL \\ Anadolu University, Faculty of Tourism, Department of Gastronomy and Culinary Arts, \\ Yunusemre Kampusu, 26470, Tepebasi, Eskisehir, Turkey, e-mail: sguler@anadolu.edu.tr

\section{Osman GÜLDEMİR*} \\ Anadolu University, Vocational School of Eskisehir, Cookery Department, Yunusemre \\ Kampusu, 26470, Tepebasi, Eskisehir, Turkey, e-mail: osmanguldemir@gmail.com
}

\section{Önder YAYLA}

Anadolu University, Faculty of Tourism, Department of Gastronomy and Culinary Arts, Yunusemre Kampusu, 26470, Tepebasi, Eskisehir, Turkey, e-mail: onder.yayla@gmail.com

\begin{abstract}
Citation: Önçel, S., Güldemir, O., \& Yayla, Ö. (2018). GEOGRAPHICAL EXPLORATION OF VEGAN DISHES FROM TURKISH CUISINE. GeoJournal of Tourism and Geosites, 23(3), 824834. https://doi.org/10.30892/gtg.23317-331
\end{abstract}

\begin{abstract}
Turkish cuisine is suitable for vegan and vegetarian diets with its healthy dishes. The aim of this study is to reveal the dishes suitable for vegan and vegetarian diets in Turkish cuisine culture and to analyze their nutritional values. Turkey is geographically divided into seven regions. In this study, 21 vegan and vegetarian recipes that are served as soup, main course and dessert from each of the seven regions in Turkey were handled. The materials used in the dishes were determined by interviews and literature. Approximately one portion of each dish was analyzed for 21 items with the Nutrition Information System. The Nutritional Information System (BeBiS) is a packaged program that allows the calculation of nutrients in the contents of foods during studies related to nutrition. BeBiS uses the nation's scientific food databases. The recipes discussed were compared and evaluated in terms of regions through nutritional facts. Findings suggest that there were significant differences between dishes from different regions for vegans and vegetarians. These results suggest that vegans can be guided by vegan samples into Turkish culinary culture.
\end{abstract}

Key words: cuisine, Turkish cuisine, vegetarian recipes, vegan recipes

\section{INTRODUCTION}

Nowadays, gastronomy, one of the most significant elements of heritage tourism (Matlovičová \& Husárová, 2017: 5), has become an important discipline that attracts people's attention. In gastronomy, vegan and vegetarian diets have become notable issues in the last decade. Veganism and vegetarianism, which are rapidly-growing trends

\footnotetext{
${ }^{*}$ Corresponding author
} 
throughout the world (Key et al., 2006: 35; Stahler, 2012; Son et al., 2016: 830; Clarkson, 2017), are not only simple eating habits or styles, they are also considered as lifestyles, life philosophies and ethical approaches (Mendes, 2013: 145). People prefer vegan/vegetarian lifestyles for various reasons: respecting the right to live, taking an ethical stand against the exploitation of animals, eliminating the damage to the environment, living a healthy life, and religious beliefs are among the reasons of these preferences (Tezcan, 1999: 217; Shani \& Dipetro, 2007: 70). Vegans refuse to consume animal products: fish, meat, marine products, eggs, dairy products, and honey. Besides their dietary habits (diets), they also refuse to use animal products such as furs or leather (Altmann, 2015: 3).

There are different styles of vegetarian nutrition:

Occasional Vegetarians: Basically eat all kinds of animal products, while trying to keep a balanced diet, and sometimes keep a vegetarian diet.

Semi-vegetarians: Eat milk and dairy products, eggs, fish, and poultry. However, they avoid eating red meat. Pesco-vegetarians: Eat milk and dairy products, eggs and fish, but avoid all other animal products.

Lacto-Ovo Vegetarians: Consume dairy products and eggs, but avoid all other animal products.

Lacto-Vegetarians: Consume dairy products, but avoid all other animal products.

Ovo-Vegetarians: Consume egg products, but avoid all other animal products.

Vegans: Neither eat nor consume animal products of any kind (including honey).

Raw Foodists: Vegans who do not cook or heat food, but eat it only in its natural, raw state.

Fruitarians: Consume only fresh fruit and food that is technically considered as fruit, such as cucumbers and tomatoes (Shani \& DiPietro, 2007: 67).

Products for vegetarians and vegans are beginning to appear on menus in restaurants, even if there are still just a few. In previous years, vegetarians had to accept vegetable-based menus. However, today, one can easily find vegetarian menus in many restaurants (Gruber, 2013: 11). Along with the increasing demand for vegetarian products and the increasing demand in healthy nutrition in recent years (Radnitz et al., 2015: 35), the variety and quality of meat-free options have increased in many restaurants. Today, the increasing number of restaurants, which aim to attract vegetarian customers through movements such as the "Meatless Monday" movement, also led other restaurants to offer meatless menus for vegetarians (Kühn, 2008: 10; Brandau, 2008: 35). While restaurants without any vegetarian themes or concepts can be visited by vegetarians (Shani \& DiPedro, 2007: 72), the menu options that can be offered by restaurants for vegetarians are still limited. Thus, changing approaches in food and beverage industry towards vegetarian food products is critical for people who have adopted a vegan or vegetarian lifestyle (Rivera \& Shani, 2013: 1062). Having a vegan/vegetarian-friendly menu will provide great advantages to restaurants in this competitive environment.

Turkish cuisine is generally known for dishes such as shish kebab (grilled meat on skewers), doner kebab (gyro), and lahmacun (a pizza with spicy meat filling). These are unfortunately - the varieties preferred by tourists, or in other words, forced to prefer when they visit Turkey. However, with its rich variety and healthy nutrients, Turkish cuisine has what it takes to pioneer the vegetarian cuisine (Tamkoç, 2006). Geography of a country plays a key role on local cuisine cultures (Matlovičová et al., 2014: 141). Because of this fact, geographical influences were the reason for excessive consumption of meat dishes in old Turkic communities. However, Turkish cuisine is also rich in terms of vegetable dishes, pies, fruit stews, soups, and other varieties. Thus, it is a cuisine that may be preferred by vegetarians (Güler, 2010: 167). Historical background and diversity, the richness of the region, and high quality products are the main elements that constitute the 
base of the Turkish cuisine. Turkish cuisine has many different foods and food types as well as diversity and suitability of taste, healthy and balanced nutrition, and even dishes that can be used as sources of vegan vegetarian cuisine. This study presents vegan and vegetarian dishes from Turkish cuisine.

\section{METHOD}

Turkey is geographically divided into seven regions. These regions are the Marmara Region, Central Anatolia Region, Aegean Region, Southeastern Anatolia Region, Eastern Anatolia Region, Black Sea Region, and Mediterranean Region (Figure 1). In this study, vegan and vegetarian recipes that are served as soup, main course and dessert from each of the seven regions in Turkey were discussed. Purposive sampling, which is generally used in qualitative analysis method (Yolal, 2016: 88), was used to determine the dishes for the study. The samples in this study are soups, main courses and desserts for each region, determined by interviews with two food experts and two nutritionists. Consequently, a total of 21 dishes were selected for the purpose of the study. The materials used in the dishes were determined by interviews and literature (Hıll, 2017; Işık, 2017; Şallı, 2017; Yıldız, 2017). Approximately one portion was analyzed of each of the 21 items with the Nutrition Information System (Erhardt, 2010). The Nutritional Information System (BeBiS) is a packaged program that allows the calculation of nutrients in the contents of foods during studies related to nutrition. BeBiS uses the nation's scientific food databases. The data are evaluated by reliable intake levels (Annex 1) from Turkey's Food and Nutrition Guide. This guide takes into account the reference values from the World Health Organization and the World Agriculture Organization: it is a scientific study based on the results of Turkey Nutrition and Health Research (Besler et al., 2015, 86-88).

\section{RESULTS}

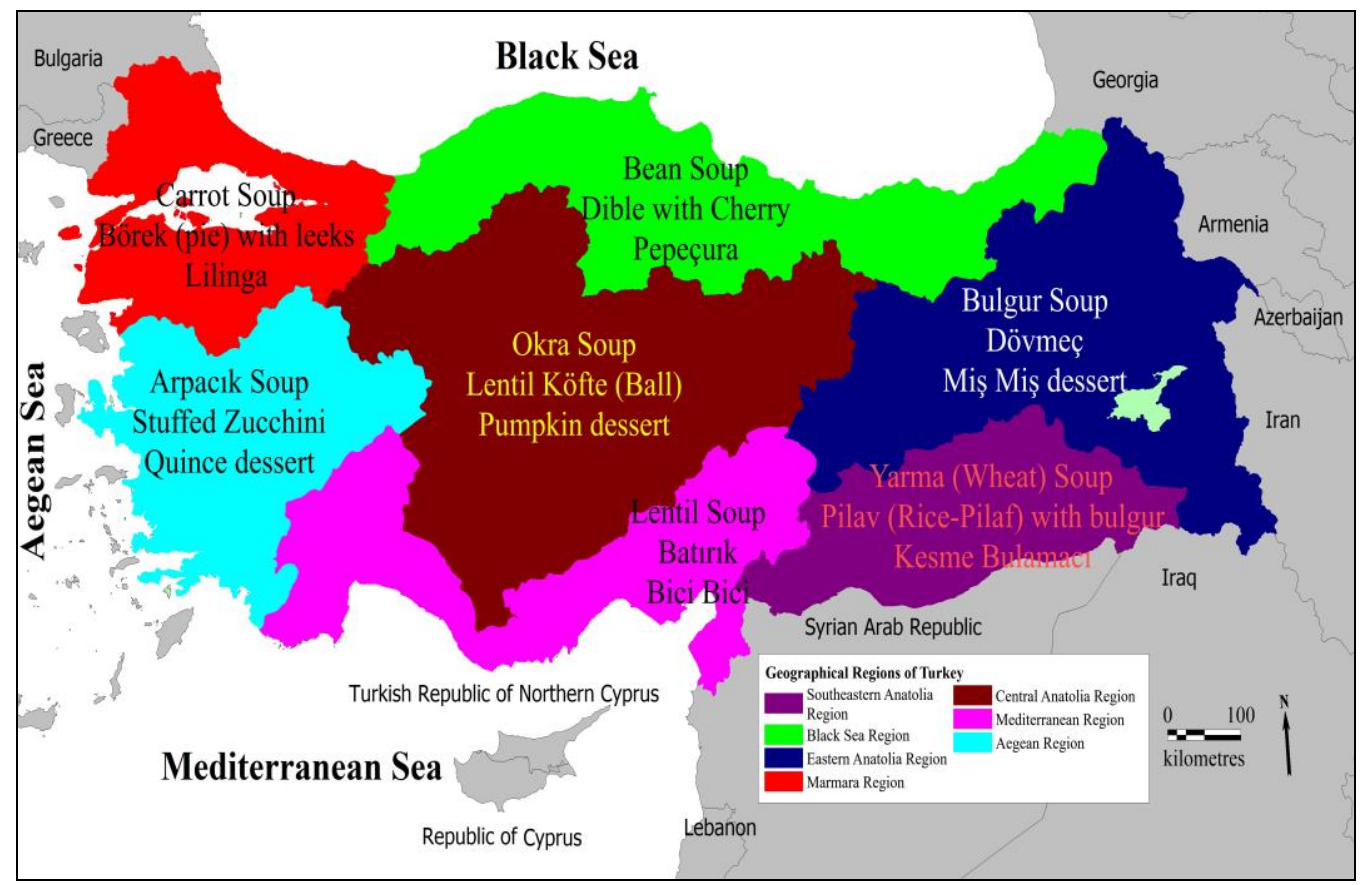

Figure 1. Geographical Regions of Turkey and Dishes that Have Chosen

(Source: Drawn in the MapInfo program, 2018) 
The dishes determined through the interviews with the experts are located in Figure 1. There are soups, main courses and desserts for each region (Hızlı, 2017; Işık, 2017; Şallı, 2017; Ylldı, 2017).

Carrot soup (Annex 2) chosen from the Marmara Region (Sarıçay, 2007; Gürsoy, 2011: 44) meets $7 \%$ of the daily needs of women and 6\% of men with an energy value of $153.9 \mathrm{kcal}$. The soup, which is very rich in vitamin A, meets daily nutritional needs as follows: $641 \%$ (F-Female) - 499\% (M-Male); 46\% of vitamin B6; $48 \%$ of vitamin $\mathrm{C}$ and 28\% (F-Female) - 19\% (M-Male) of Omega 6 (Table 1-A) (Erhardt, 2010). The soup contains ingredients (Baysal, 2004) which have a positive effect on eyes, skin and mental health, and it is found to be practical and fast in terms of preparation and cooking.

Table 1-A. Analysis of the Dishes-Nutritional Values About 1 Serving (Data source: Erhardt, 2010)

\begin{tabular}{|l|c|c|c|c|c|c|c|}
\hline & $\begin{array}{c}\text { Carrot } \\
\text { Soup }\end{array}$ & Börek & Lilinga & $\begin{array}{c}\text { Okra } \\
\text { Soup }\end{array}$ & $\begin{array}{c}\text { Lentil } \\
\text { Köfte }\end{array}$ & $\begin{array}{c}\text { Pumpkin } \\
\text { Dessert }\end{array}$ & $\begin{array}{c}\text { Arpacik } \\
\text { Soup }\end{array}$ \\
\hline Energy (kcal) & 153.9 & 415.9 & 174.2 & 48.1 & 263.0 & 258.3 & 158.9 \\
\hline Protein (g) & 3.2 & 14.4 & 3.9 & 1.9 & 8.9 & 3.7 & 5.7 \\
\hline Fibre (g) & 7.7 & 8.5 & 1.2 & 3.5 & 8.3 & 4.8 & 3.9 \\
\hline Vitamin A (mcg) & 4489.8 & 338.5 & 3.7 & 70.4 & 68.7 & 254.8 & 146.6 \\
\hline Vitamin D (mcg) & 0.0 & 0.0 & 0.0 & 0.0 & 0.0 & 0.0 & 0.1 \\
\hline Vitamin E (mg) & 3.9 & 3.2 & 0.5 & 1.7 & 1.2 & 2.1 & 1.1 \\
\hline Thiamine (mg) & 0.1 & 0.2 & 0.1 & 0.1 & 0.2 & 0.1 & 0.1 \\
\hline Riboflavin (mg) & 0.1 & 0.2 & 0.0 & 0.1 & 0.1 & 0.1 & 0.1 \\
\hline Niacin (mg) & 1.2 & 1.8 & 0.4 & 0.8 & 3.1 & 1.1 & 1.2 \\
\hline Vitamin B6 (mg) & 0.6 & 0.7 & 0.1 & 0.1 & 0.4 & 0.3 & 0.2 \\
\hline Vitamin B12 (mcg) & 0.0 & 0.0 & 0.0 & 0.0 & 0.0 & 0.0 & 0.0 \\
\hline Folate (mcg) & 47.1 & 123.1 & 9.2 & 58.2 & 46.4 & 75.9 & 42.9 \\
\hline Vitamin C (mg) & 43.4 & 48.8 & 1.8 & 25.3 & 11.2 & 24.1 & 12.8 \\
\hline Sodium (mg) & 903.9 & 17.1 & 2.1 & 414.4 & 795.3 & 2.3 & 807.6 \\
\hline Calcium (mg) & 92.8 & 191.5 & 25.5 & 78.1 & 51.1 & 53.8 & 61.5 \\
\hline Phosphorus (mg) & 87.1 & 167.9 & 70.7 & 59.9 & 266.5 & 129.8 & 104.3 \\
\hline Iron (mg) & 1.7 & 3.6 & 0.9 & 1.0 & 4.2 & 2.0 & 1.6 \\
\hline Zinc (mg) & 1.0 & 1.7 & 0.5 & 0.8 & 2.4 & 0.7 & 1.0 \\
\hline Omega 3 (g) & 0.1 & 0.2 & 0.7 & 0.0 & 0.1 & 0.8 & 0.1 \\
\hline Omega 6 (g) & 3.3 & 2.5 & 3.8 & 1.3 & 0.6 & 3.7 & 0.5 \\
\hline Cholesterol (mg) & 0.0 & 0.0 & 0.0 & 0.0 & 0.0 & 0.0 & 12.5 \\
\hline
\end{tabular}

Börek (pie) with leeks (Annex 2) selected from the Marmara Region (Bandirmalı, 2007; Gürsoy, 2011: 534) contains 415.9 kcal energy value, which covers 20\% of women's daily needs and $16 \%$ of men's. It meets daily nutritional needs as follows: $29 \%$ (F)- 24\% (M) of protein; 34\% (F)-29\% (M) of fibre; $54 \%$ of vitamin B6; 54\% of vitamin C and 24\% of phosphor (Table 1-A) (Erhardt, 2010). It includes nutrients for renewal of the body for healthy digestive and respiratory systems (Baysal, 2004). However, it is difficult to make, as it takes time and needs expertise in terms of the cooking method.

Lilinga (a kind of dessert with molasses) (Annex 2) selected from the Marmara Region (Güldemir, 2007: 36) has 174.2 kcal energy value. Lilinga meets 8\% (F)-7\% (M) of daily nutritional requirements. It meets daily nutritional needs as follows: 9\% (F)-8\% (M) of thiamine; $10 \%$ phosphorus and 32\% (F)- 22\% (M) of omega 6 (Table 1A) (Erhardt, 2010). It contains nutrients that are good for circulation, nervous systems, energy metabolism, and skeletal structure (Baysal, 2004).

Okra soup (Annex 2) selected from the Central Anatolia Region (Halıcı, 2014: 40) contains $48.1 \mathrm{kcal}$, which is quite low. The recipe meets daily nutritional needs as 
follows: $14 \%(\mathrm{~F})-12 \%(\mathrm{M})$ of fibre; $11 \%$ of vitamin $\mathrm{E}$; $15 \%$ of folate and $28 \%$ of vitamin $\mathrm{C}$ (Table 1-A) (Erhardt, 2010). It contains nutritional ingredients that are known to have positive effects on the digestive system, circulatory system, immune system, vitamin metabolism and muscle health (Baysal, 2004).

Lentil Köfte (Ball) (Annex 2) selected from the Central Anatolia Region (Eryllmaz, 2011: 513) meets 13\% (F)-10\% (M) of daily requirement with an energy value of $263 \mathrm{kcal}$. It meets daily nutritional needs as follows: $18 \%(\mathrm{~F})-15 \%(\mathrm{M})$ of protein; $33 \%(\mathrm{~F})-$ $29 \%(\mathrm{M})$ of fibre; $22 \%(\mathrm{~F})-19 \%(\mathrm{M})$ of niacin and $24 \%(\mathrm{~F})-22 \%(\mathrm{M})$ of zinc (Table $1-\mathrm{A})$ (Erhardt, 2010). The lentil dish, which is highly balanced in terms of nutritional composition, was evaluated positively in terms of taste and health.

Pumpkin Dessert (Annex 2) selected from the Central Anatolia Region (Karadağ et al., 2014: 73) contains $258.3 \mathrm{kcal}$ energy and meets 13\% of women's and 10\% of men's daily needs. It meets daily nutritional needs as follows: $19 \%(\mathrm{~F})-17 \%(\mathrm{M})$ of fibre; $36 \%$ (F)-28\% (M) of vitamin A; $23 \%$ of vitamin B6; $19 \%$ of phosphorus and $31 \%(\mathrm{~F})-22 \%(\mathrm{M})$ of omega 6 (Table 1-A) (Erhardt, 2010). It contains nutrients that have positive effects on eyes, bones and skin health, and immune and circulatory systems (Baysal, 2004).

Arpack soup (Annex 2) selected from the Aegean Region (Kiraz, 2007: 28) contains low energy with 158,9 kcal. It meets daily nutritional needs as follows: $16 \%(\mathrm{~F})-$ $13 \%(\mathrm{M})$ of fibre, $21 \%(\mathrm{~F})-16 \%(\mathrm{M})$ of vitamin A, $15 \%$ of vitamin $\mathrm{B} 6$, and $10 \%(\mathrm{~F})-9 \%(\mathrm{M})$ of zinc (Table 1-A) (Erhardt, 2010). It contains nutrients that are good for skin and eye health; digestive, immune and respiratory systems, and sexual life. It takes a long time to prepare arpacık soup, but it is quick and practical to cook.

Table 1-B. Analysis of the Dishes-Nutritional Values About 1 Serving (Data source: Erhardt, 2010)

\begin{tabular}{|l|c|c|c|c|c|c|c|}
\hline & $\begin{array}{c}\text { Stuffed } \\
\text { Zucchini }\end{array}$ & $\begin{array}{c}\text { Quince } \\
\text { Dessert }\end{array}$ & $\begin{array}{c}\text { Yarma } \\
\text { Soup }\end{array}$ & $\begin{array}{c}\text { Pilav with } \\
\text { Bulgur }\end{array}$ & $\begin{array}{c}\text { Kesme } \\
\text { Bulamaci }\end{array}$ & $\begin{array}{c}\text { Bulgur } \\
\text { Soup }\end{array}$ & Dövmeç \\
\hline Energy (kcal) & 225.5 & 411.1 & 190.6 & 460.6 & 217.3 & 105.2 & 154.6 \\
\hline Protein (g) & 7.8 & 1.3 & 3.9 & 8.6 & 4.1 & 1.8 & 3.5 \\
\hline Fibre (g) & 5.0 & 7.2 & 3.6 & 10.8 & 2.3 & 2.1 & 5.0 \\
\hline Vitamin A (mcg) & 219.5 & 10.6 & 1.6 & 60.6 & 8.5 & 9.5 & 167.1 \\
\hline Vitamin D (mcg) & 0.0 & 0.0 & 0.0 & 0.0 & 0.0 & 0.0 & 0.0 \\
\hline Vitamin E (mg) & 7.8 & 0.8 & 6.5 & 13.4 & 1.4 & 0.7 & 7.7 \\
\hline Thiamine (mg) & 0.2 & 0.1 & 0.1 & 0.3 & 0.2 & 0.1 & 0.2 \\
\hline Riboflavin (mg) & 0.3 & 0.1 & 0.0 & 0.1 & 0.1 & 0.0 & 0.1 \\
\hline Niacin (mg) & 1.6 & 0.4 & 1.6 & 3.9 & 1.3 & 0.8 & 1.6 \\
\hline Vitamin B6 (mg) & 0.3 & 0.1 & 0.2 & 0.5 & 0.2 & 0.1 & 0.3 \\
\hline Vitamin B12 (mcg) & 0.0 & 0.0 & 0.0 & 0.0 & 0.0 & 0.0 & 0.0 \\
\hline Folate (mcg) & 138.3 & 13.7 & 19.8 & 58.6 & 20.4 & 8.7 & 107.9 \\
\hline Vitamin C (mg) & 52.3 & 18.9 & 2.4 & 33.7 & 4.5 & 2.2 & 54.9 \\
\hline Sodium (mg) & 790.6 & 5.4 & 7.2 & 10.3 & 8.6 & 2.7 & 407.9 \\
\hline Calcium (mg) & 114.4 & 25.8 & 30.8 & 44.3 & 98.1 & 11.4 & 54.4 \\
\hline Phosphorus (mg) & 140.6 & 45.6 & 115.0 & 288.8 & 133.3 & 62.9 & 90.8 \\
\hline Iron (mg) & 5.1 & 1.4 & 1.2 & 4.4 & 2.3 & 0.9 & 1.6 \\
\hline Zinc (mg) & 1,2 & 0.4 & 1.1 & 2.7 & 1.2 & 0.6 & 0.7 \\
\hline Omega 3 (g) & 0.3 & 0.0 & 0.1 & 0.1 & 0.4 & 0.0 & 0.1 \\
\hline Omega 6 (g) & 6.4 & 0.6 & 6.4 & 12.6 & 3.1 & 0.5 & 6.4 \\
\hline Cholesterol (mg) & 0.0 & 0.0 & 0.0 & 0.0 & 0.0 & 0.0 & 0.0 \\
\hline
\end{tabular}

Stuffed Zucchini (Annex 2) selected from the Aegean Region contains 225.5 kcal, which accounts for $11 \%$ of women's daily energy needs and $9 \%$ of men's. It meets 
daily nutritional needs as follows: $16 \%(\mathrm{~F})-13 \%(\mathrm{M})$ of protein; $20 \%(\mathrm{~F})-17 \%(\mathrm{M})$ of fibre; $31 \%(\mathrm{~F})-24 \%(\mathrm{M})$ of vitamin A; $52 \%$ of vitamin E; $27 \%(\mathrm{~F})-23 \%(\mathrm{M})$ of riboflavin; $35 \%$ of folate; $58 \%$ of vitamin $\mathrm{C}$ and $28 \%(\mathrm{~F})-51 \%(\mathrm{M})$ of iron (Table 1-B) (Erhardt, 2010). It contains nutrients which have positive effects on circulatory, respiratory, digestive and immune systems, eye health and blood structure (Baysal, 2004).

Quince Dessert (Annex 2) selected from the Aegean Region contains $411.1 \mathrm{kcal}$ energy and $20 \%$ of women's daily energy needs and $16 \%$ of men's. It meets daily nutritional needs as follows: 29\% (F)-25\% (M) of fibre; $21 \%$ of vitamin C and 8\% (F)-14\% (M) of iron (Table 1-B) (Erhardt, 2010). It contains nutrients that are good for digestive and respiratory systems, blood structure, mind, and sexual health (Baysal, 2004).

Yarma (Wheat) Soup (Annex 2) selected from the Southeast Anatolian Region contains $190.6 \mathrm{kcal}$, which corresponds to $9 \%$ of women's daily requirement and $7 \%$ of men's. It meets daily nutritional needs as follows: 8\% (F)-7\% (M) of protein, $14 \%$ (F)-12\% (M) of fibre, $43 \%$ of vitamin E, $11 \%(\mathrm{~F})-10 \%(\mathrm{M})$ of niacin, $15 \%$ of vitamin $\mathrm{B} 6$, $16 \%$ of phosphorus and $53 \%(\mathrm{~F})-38 \%(\mathrm{M})$ of Omega 6 (Table 1-B) (Erhardt, 2010). It contains nutrients that are good for circulation, immune, nervous and digestive systems, bone structure, vascular and sexual health (Baysal, 2004).

Pilav (Rice-Pilaf) with Bulgur (Annex 2) selected from the Southeast Region is widely consumed in Turkey in different forms. The recipe covered in this study meets $22 \%$ of women's daily energy requirement and $18 \%$ of men's daily energy requirement with $460.6 \mathrm{kcal}$ energy value. It meets daily nutritional needs as follows: $17 \%(\mathrm{~F})-14 \%(\mathrm{M})$ of protein, $43 \%(\mathrm{~F})-37 \%(\mathrm{M})$ of fibre, $89 \%$ of vitamin E, $27 \%(\mathrm{~F})-25 \%(\mathrm{M})$ of thiamine, $28 \%$ (F)-24\% (M) of niacin, 38\% of vitamin B6, 41\% of phosphorus and $105 \%(\mathrm{~F})-74 \%(\mathrm{M})$ of omega 6 (Table 1-B) (Erhardt, 2010). It contains nutrients that are good for renewal of the cells; digestion, circulation and immune systems and bone health (Baysal, 2004).

Kesme Bulamaci (a kind of dessert with molasses) (Annex 2) chosen from the Southeast Region (Işık, 2006: 247; Halıcı, 2015: 150) meets 11\% of women's daily energy requirements and $8 \%$ of men with $217.3 \mathrm{kcal}$ energy. It meets daily nutritional needs as follows: $9 \%(\mathrm{~F})-8 \%(\mathrm{M})$ of fibre, $9 \%$ of vitamin $\mathrm{E}, 18 \%(\mathrm{~F})-17 \%(\mathrm{M})$ of thiamine, $15 \%$ of vitamin B6, $10 \%$ of calcium and 19\% of phosphorus (Table 1-B) (Erhardt, 2010). It contains nutrients with positive effects on skeletal, digestive, nervous and immune systems, and sexual health (Baysal, 2004).

Bulgur soup (Annex 2) selected from the Eastern Anatolia Region is low on energy with a value of $105.2 \mathrm{kcal}$. It meets daily nutritional needs as follows: $8 \%(\mathrm{~F})-7 \%$ (M) of fibre, $9 \%(\mathrm{~F})-8 \%(\mathrm{M})$ of thiamine and $9 \%$ of phosphorus (Table 1-B) (Erhardt, 2010). It contains nutrients that are good for the digestive and immune systems and bone health (Baysal, 2004).

Dövmeç (a kind of eggplant dish) (Annex 2) selected from the Eastern Anatolia Region (Karadağ et al., 2014: 102-103) is low on energy with of $154.6 \mathrm{kcal}$. It meets daily nutritional needs as follows: $20 \%(\mathrm{~F})-17 \%(\mathrm{M})$ of fibre, $24 \%(\mathrm{~F})-19 \%(\mathrm{M})$ of vitamin A, $51 \%$ of vitamin $\mathrm{E}, 27 \%$ of folate, $61 \%$ of vitamin $\mathrm{C}, 13 \%$ of phosphorus and $53 \%(\mathrm{~F})-38 \%(\mathrm{M})$ of omega 6 (Table 1-B) (Erhardt, 2010). It contains nutrients that are good for digestive, nervous, respiratory, and immune systems; the eye, skin, and bone health (Baysal, 2004).

Miş Miş (Apricot) Dessert (Annex 2) selected from the Eastern Anatolia Region contains $388 \mathrm{kcal}$, which accounts for $19 \%$ of women's daily energy needs and $15 \%$ of men's. It meets daily nutritional needs as follows: $182 \%(\mathrm{~F})-142 \%(\mathrm{M})$ of vitamin A, $18 \%(\mathrm{~F})-15 \%(\mathrm{M})$ of riboflavin, $23 \%$ of vitamin $\mathrm{B} 6,20 \%$ of phosphorus and $18 \%(\mathrm{~F})-$ $32 \%(\mathrm{M})$ of iron (Table 1-C) (Erhardt, 2010). It contains nutrients, which are good for the eyes, blood and bone health and the digestive system (Baysal, 2004). 
Sibel ÖNÇEL, Osman GÜLDEMİR, Önder YAYLA

Table 1-C. Analysis of the Dishes-Nutritional Values About 1 Serving (Data source: Erhardt, 2010)

\begin{tabular}{|l|c|c|c|c|c|c|c|}
\hline & Miş Miş & $\begin{array}{c}\text { Bean } \\
\text { Soup }\end{array}$ & $\begin{array}{c}\text { Dible with } \\
\text { Cherry }\end{array}$ & Pepeçura & $\begin{array}{c}\text { Lentil } \\
\text { Soup }\end{array}$ & Batırık & Bici Bici \\
\hline Energy (kcal) & 388.0 & 153.0 & 430.1 & 296.5 & 253.9 & 340.3 & 287.0 \\
\hline Protein (g) & 5.9 & 3.2 & 6.3 & 1.7 & 13.0 & 9.0 & 0.7 \\
\hline Fibre (g) & 8.1 & 3.9 & 2.5 & 1.6 & 6.7 & 8.0 & 1.8 \\
\hline Vitamin A (mcg) & 1277.0 & 42.3 & 9.1 & 9.6 & 36.2 & 97.5 & 6.4 \\
\hline Vitamin D (mcg) & 0.0 & 0.0 & 0.0 & 0.0 & 0.0 & 0.0 & 0.0 \\
\hline Vitamin E (mg) & 1.8 & 6.3 & 7.5 & 1.1 & 4.2 & 1.2 & 0.1 \\
\hline Thiamine (mg) & 0.2 & 0.1 & 0.1 & 0.1 & 0.3 & 0.3 & 0.0 \\
\hline Riboflavin (mg) & 0.2 & 0.1 & 0.1 & 0.1 & 0.2 & 0.1 & 0.0 \\
\hline Niacin (mg) & 2.4 & 1.0 & 1.3 & 0.5 & 1.8 & 3.0 & 0.4 \\
\hline Vitamin B6 (mg) & 0.3 & 0.3 & 0.2 & 0.1 & 0.4 & 0.4 & 0.0 \\
\hline Vitamin B12 (mcg) & 0.0 & 0.0 & 0.0 & 0.0 & 0.0 & 0.0 & 0.0 \\
\hline Folate (mcg) & 21.6 & 40.6 & 31.0 & 8.9 & 120.9 & 51.6 & 12.8 \\
\hline Vitamin C (mg) & 27.1 & 16.9 & 11.0 & 6.6 & 10.3 & 25.2 & 52.0 \\
\hline Sodium (mg) & 21.0 & 785.0 & 9.0 & 4.8 & 824.0 & 787.8 & 9.2 \\
\hline Calcium (mg) & 80.3 & 76.3 & 22.9 & 36.0 & 70.9 & 77.8 & 51.5 \\
\hline Phosphorus (mg) & 138.0 & 79.9 & 118.6 & 52.9 & 231.6 & 297.2 & 24.4 \\
\hline Iron (mg) & 3.2 & 1.4 & 0.8 & 1.1 & 4.1 & 4.3 & 1.0 \\
\hline Zinc (mg) & 1.0 & 1.0 & 0.5 & 0.4 & 2.3 & 2.6 & 0.7 \\
\hline Omega 3 (g) & 0.7 & 0.1 & 0.1 & 0.0 & 0.1 & 1.2 & 0.1 \\
\hline Omega 6 (g) & 3.8 & 6.2 & 7.5 & 0.2 & 3.4 & 6.6 & 0.1 \\
\hline Cholesterol (mg) & 0.0 & 0.0 & 0.0 & 0.0 & 0.0 & 0.0 & 0.0 \\
\hline
\end{tabular}

Bean soup (Annex 2) selected from the Black Sea Region is low on energy, and it contains $153 \mathrm{kcal}$ of energy. It meets daily nutritional needs as follows: $16 \%(\mathrm{~F})-13 \%(\mathrm{M})$ of fibre, $42 \%$ of vitamin $\mathrm{E}, 23 \%$ of vitamin $\mathrm{B} 6,10 \%$ of folate, $19 \%$ of vitamin $\mathrm{C}, 11 \%$ of phosphorus, $10 \%(\mathrm{~F})-9 \%(\mathrm{M})$ of zinc and $52 \%(\mathrm{~F})-36 \%(\mathrm{M})$ of omega 6 (Table 1-C) (Erhardt, 2010). It contains nutrients with positive effects on digestive and immune systems, bone and eye health (Baysal, 2004).

Dible with Cherry (a kind of rice and cherry dish) (Annex 2) selected from the Black Sea Region (Güldemir and Halıcı, 2009: 562) is only consumed in the Black Sea Region in Turkey, so it is an original recipe. It contains $430.1 \mathrm{kcal}$ energy and covers $21 \%$ of women's daily needs and $16 \%$ of men's. It meets daily nutritional needs as follows: $13 \%(\mathrm{~F})-11 \%(\mathrm{M})$ of protein, $50 \%$ of vitamin $\mathrm{E}, 15 \%$ of vitamin $\mathrm{B} 6,12 \%$ of vitamin $\mathrm{C}, 17 \%$ of phosphorus and 63\% (F)-44\% (M) of omega 6 (Table 1-C) (Erhardt, 2010). It contains nutrients that are good for renewal of the cells; skeletal, digestive, respiratory and circulatory systems (Baysal, 2014).

Pepeçura (Annex 2) selected from the Black Sea Region (Güldemir and Halıcı, 2009: 562) is a special dessert in the Black Sea Region. It contains 296.5 kcal energy, which is $14 \%$ of women's daily needs of and $11 \%$ of men's. It meets daily nutritional needs as follows: $6 \%(\mathrm{~F})-6 \%(\mathrm{M})$ of fibre, $9 \%(\mathrm{~F})-8 \%(\mathrm{M})$ of thiamine, $9 \%(\mathrm{~F})-8 \%(\mathrm{M})$ of Riboflavin, 8\% of phosphorus and 6\% (F)-11\% (M) of iron (Table 1-C) (Erhardt, 2010). It contains nutrients that are good for nervous, immune, and respiratory systems; bone and muscle health (Baysal, 2004).

Lentil soup (Annex 2) chosen from the Mediterranean region is prepared with similar ingredients and methods in almost every part of Turkey. It contains $13 \%$ of women's daily energy requirements and 10\% of men's daily energy requirements with an energy content of $253.9 \mathrm{kcal}$. It meets daily nutritional needs as follows: $26 \%(\mathrm{~F})-22 \%(\mathrm{M})$ of protein, $27 \%(\mathrm{~F})-23 \%(\mathrm{M})$ of fibre, $28 \%$ of vitamin E, $27 \%(\mathrm{~F})-25 \%(\mathrm{M})$ of thiamine, $31 \%$ of 
vitamin $\mathrm{B} 6,30 \%$ of folate, $33 \%$ of phosphorus, $23 \%(\mathrm{~F})-41 \%(\mathrm{M})$ of iron and $23 \%(\mathrm{~F})-21 \%$ (M) of zinc (Table 1-C) (Erhardt, 2010). It contains nutrients with positive effects on skeletal, nervous, and respiratory systems; blood health and energy metabolism (Baysal, 2004).

Batırık (a kind of mix with bulgur) (Annex 2) selected from the Mediterranean region (Baysal et al., 2001: 205; Karadağ et al., 2014: 54) is consumed frequently, especially in the Eastern Mediterranean Region. It meets $16 \%$ of women's daily energy needs and $13 \%$ of men's daily energy needs with an energy content of $340.3 \mathrm{kcal}$. It meets daily nutritional needs as follows: $18 \%(\mathrm{~F})-15 \%(\mathrm{M})$ of protein, $32 \%(\mathrm{~F})-28 \%(\mathrm{M})$ of fibre, $27 \%(\mathrm{~F})-25 \%(\mathrm{M})$ of thiamine, $21 \%(\mathrm{~F})-19 \%(\mathrm{M})$ of niacin, $31 \%$ of vitamin $\mathrm{B} 6,28 \%$ of vitamin C, 42\% of phosphorus, $24(\mathrm{~F})-43 \%(\mathrm{M})$ of iron, 26\% (F)-24\% (M) of zinc and 55\% (F)-39\% (M) of omega (Table 1-C) (Erhardt, 2010). It contains nutrients that are good for skeletal structure, blood, and skin health; nervous and respiratory systems (Baysal, 2004).

Bici Bici (a kind of dessert with starch and sugar) (Annex 2) selected from the Mediterranean region (Karadağ at al., 2014: 59) is a regional specialty. It covers only $14 \%$ of women's daily energy needs and $11 \%$ of men with 287 kcal content. It meets daily nutritional needs as follows: $58 \%$ of vitamin $\mathrm{C}, 6 \%(\mathrm{~F})-10 \%(\mathrm{M})$ of iron and $7 \%(\mathrm{~F})-$ 6\% (M) of zinc (Table 1-C) (Erhardt, 2010). It contains nutrients which have positive effects on respiratory, immune and nervous systems; and skin health (Baysal, 2004).

Annex 1. Reliable Intake Levels for Recommended Daily Energy and Nutrients for Turkey (Data source: Besler et al., 2015: 86-88)

\begin{tabular}{|l|c|c|c|c|}
\hline \multirow{2}{*}{ Nutrients } & \multicolumn{4}{c|}{ Recommended Intake } \\
\cline { 2 - 5 } & \multicolumn{2}{|c|}{ Female (age) } & \multicolumn{2}{c|}{ Male (age) } \\
\cline { 2 - 5 } & $\mathbf{1 9 - 3 0}$ & $\mathbf{3 1 - 5 0}$ & $\mathbf{1 9 - 3 0}$ & $\mathbf{3 1 - 5 0}$ \\
\hline Energy (kcal) & 2065 & 1917 & 2850 & 2623 \\
\hline Protein (g) & 50 & 52 & 58 & 60 \\
\hline Fibre (g) & 25 & 21 & 29 & 29 \\
\hline Vitamine A (mcg) & 700 & 700 & 900 & 900 \\
\hline Vitamine D (mcg) & 10 & 10 & 10 & 10 \\
\hline Vitamine E (mg) & 15 & 15 & 15 & 15 \\
\hline Thiamine (mg) & 1,1 & 1,1 & 1,2 & 1,2 \\
\hline Riboflavin (mg) & 1,0 & 1,1 & 1,3 & 1,3 \\
\hline Niacin (mg) & 14 & 14 & 16 & 16 \\
\hline Vitamine B6 (mg) & 1,3 & 1,3 & 1,3 & 1,3 \\
\hline Vitamine B12 (mcg) & 2,4 & 2,4 & 2,4 & 2,4 \\
\hline Folate (mcg) & 400 & 400 & 400 & 400 \\
\hline Vitamine C (mg) & 90 & 90 & 90 & 90 \\
\hline Sodium (m) & - & - & - & - \\
\hline Calcium (mg) & 1000 & 1000 & 1000 & 1000 \\
\hline Phosphorus (mg) & 700 & 700 & 700 & 700 \\
\hline Iron (m) & 18 & 18 & 10 & 10 \\
\hline Zinc (mg) & 10 & 10 & 11 & 11 \\
\hline Omega 3 (g) & 1.1 & 1.1 & 1.6 & 1.6 \\
\hline Omega 6 (g) & 12 & 12 & 17 & 17 \\
\hline Cholesterol (mg) & - & - & - & - \\
\hline
\end{tabular}

\section{CONCLUSION}

Turkish cuisine is very rich in terms of diversity, as well as foods suitable for healthy and clean eating. Such richness can contribute to satisfy both frugal needs of tourists and gourmet tourist (Privitera et al., 2018: 154). Thanks to Turkey's beautiful climate and geography, it is home to many different fruits and vegetables. 
Sibel ÖNÇEL, Osman GÜLDEMİR, Önder YAYLA

Annex 2. Photograps of Vegan Vegetarian Dishes Selected by Region

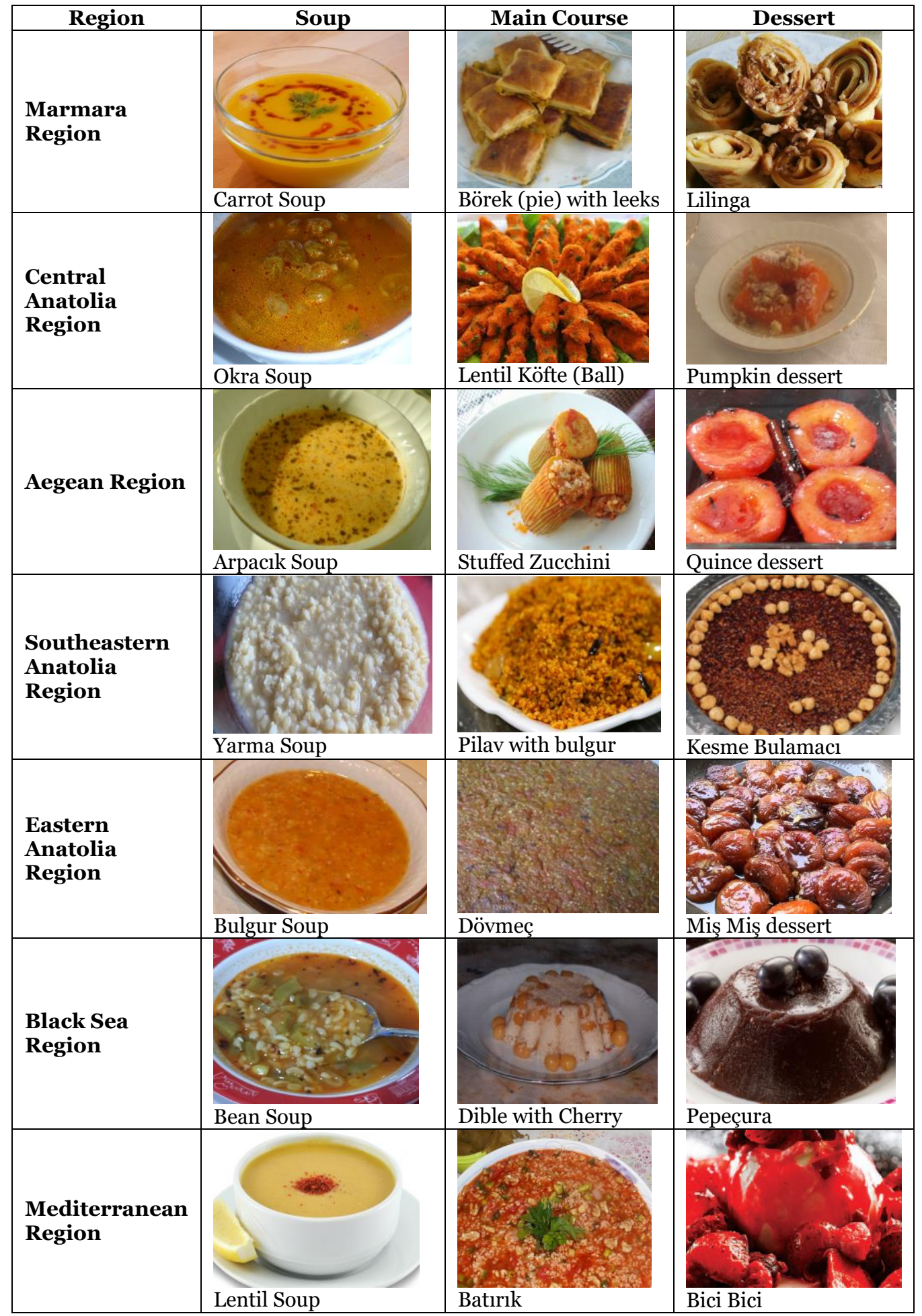


Therefore, it is very easy to grow appropriate foods for vegan diet. In this study, 21 vegetarian dishes consisting of soups, main dishes and desserts from seven regions of Turkey were analyzed. Although cereal-based recipes and popular meat-based meals are known in Turkish cuisine, there are dishes suitable for vegan and vegetarian diets in different regions. Interviews with experts and literature reviews show that the Marmara, Aegean and Black Sea regions contain dishes suitable for vegans. Although there are different examples in other regions as well as those included in the study, compared to the Marmara, Aegean and Black Sea regions, less vegan vegetarian diet patterns are found. When the analyzed dishes are evaluated; vitamin E, vitamin A, thiamine, riboflavin, niacin, vitamin B6, folate, vitamin $\mathrm{C}$, calcium, phosphorus, iron, zinc, and omega 6 needs can be met for women and men. However, it is understood that vitamin D, vitamin B12, and omega 3 are not sufficient to meet the requirements.

This is also the case with cuisines of other countries. In this study, 'Pilav (RicePilaf) with Bulgur' was found to be the richest meal in terms of energy, fiber, vitamin E, thiamine, niacin, iron, zinc, and omega 6 . Thus, it can be concluded that it is the most useful dish for vegan nutrition among all the dishes analyzed in this study. 'Börek (Pie) with Leek' was found to be the richest meal in terms of protein, vitamin B6 and calcium. 'Batırık (a kind of mix with bulgur)' was found to be rich in thiamine, phosphorus and omega 3. 'Carrot Soup' was found to be rich in vitamin A; 'Arpacik Soup' was found to be rich in vitamin D; 'Lentil Soup' was found to be rich in thiamine; 'Stuffed Zucchini' was found to be rich in riboflavin; and 'Bici Bici (a kind of dessert with starch and sugar)' was found to be rich in vitamin $\mathrm{C}$.

One of the major problems of vegan tourists is the difficulty of finding food that is rich in nutritional value in the destinations visited. Considering the vegan and vegetarian dishes in the world, samples of Turkish cuisine that are included in this study are suggested ingredients for the healthy nutrition of vegans. In future studies, it is suggested to increase the number of dishes to enrich the experimental food preparation practices for the benefit of vegans and thus to develop recipes suitable for vegans.

\section{Acknowlegments}

This work was supported by the Anadolu University Scientific Research Projects [grant number 1703E065].

\section{REFERENCES}

Altmann, K. (2015). Vegetarismus in Deutschland. [Vegetarianism in Germany]. Vegetarismusstudie der Üniversitaet Jena und Buchvorstellung von Karen Duves “Anstaendig Essen”, Germany: GRIN Publishing.

Bandırmalı, H. (2007). Interview with Osman Güldemir. Personal interview, Eskişehir.

Baysal, A. (2004). Beslenme [Nutrition]. Ankara: Hatiboğlu Basım.

Baysal, A., Başoğlu, S., \& Karabudak, E. (2001). Vejetaryen Yemekleri [Vegatarian Foods]. Ankara: Özgür Yayınları. Besler, H.T., Rakıcıŏlu, N., Ayaz, A., Demirel, Z.B., Özel, H.G., Samur, G.E., Yıldız, E.A., Bilgiç, P., Dikmen, D., Göktaş, Z., Kızıl, M., Mutlu, A.A., Ünal, R.N., Fisunoğlu, M., Güleç, A., Çiftçi, S., Ede, G., Erçim, R.E., Kabasakal, A., Yılmaz, D., \& Yürük, A. (2015). Türkiye’ye Özgü Besin ve Beslenme Rehberi [Turkey's Food and Nutrition Guide]. Ankara: Hacettepe Üniversitesi Sağlık Bilimleri Fakültesi Beslenme ve Diyetetik Bölümü.

Brandau, M. (2008). Maoz moves to capture U.S. vegetarian market. Nation's Restaurant News, November 10, http://www.nrn.com/archive/maoz-moves-capture-us-vegetarian-market.

Erhardt, J. (2010). Beslenme Bilgi Sistemi (BeBiS) [Nutrition Information System] 7.1 Full Version. Stuttgart: Entwickelt an der Universität Hohenheim.

Eryılmaz, L. (2011). Yemek Pişirme Teknikleri-Çeşitleri Beslenme Yemek Görgü Kuralları [Cooking TechniquesNutrition-Food Etiquette Rules]. İstanbul: Remzi Kitabevi.

Clarkson, D. (2017). Business and entrepreneurs seize opportunities in rise of veganism. The Guardian, November 28, 2017, https://www.theguardian.com/sustainable-business/2014/nov/28/business-andentrepreneurs- seize-opportunities-in-rise-of-veganism. 
Gruber, M., (2003). Die Zukunft is(s)t Vegetarisch [The future is(t) vegetarian]. Hamburg: Diplomica Verlag.

Güldemir, O., \& Halıcı, N. (2009). "Özel Bir Lezzet: Kiraz Diblesi. [A Special Taste: Cherry Dible]" Poster presented at the II. Geleneksel Gıdalar Sempozyumu, Van Yüzüncüyll University, May 27-29, 2009.

Güldemir, O. (2007). Bilecik Mutfak Kültürü ve Yemekleri Araştırması [Bilecik Cuisine Research. Konya: Selçuk University, Mesleki Eğitim Fakültesi, Aile Ekonomisi ve Beslenme Öğretmenliği ABD.

Güler, S. (2010). “Türk Mutfak Kültürü ve Tarihsel Gelişimi [Turkish Cuisine and Historical Development]” in Kültürel Miras Yönetimi [Cultural Heritage Management], 162-181, Eskişehir Anadolu Üniversitesi Yayın No: 2126, 2010.

Gürsoy, D. (2011). Kuzeyden Güneye... Doğudan Batıya Yöresel Mutfağımız [From the North to the South ... from East to West Our Regional Cuisine]. İstanbul: Oğlak Yayıncılık.

Halıcı, N. (2013). Açıklamalı Yemek ve Mutfak Terimleri Sözlüğü [Explanatory Cooking and Kitchen Glossary] İstanbul: Oğlak Yayıncılık.

Halıcı, N. (2014). Konya Mutfağı [Konya Cuisine]. Konya: Selçuklu Belediyesi Yayınları.

Halıcı, N. (2015). Güneydoğu Anadolu Bölgesi Mutfak Kültürü ve Yemekleri [Southeast Anatolia Region Cuisine]. İstanbul: Oğlak Yayıncılı.

Hızlı, H. (2017). Interview with Osman Güldemir. Personal interview, Eskişehir, May 28, 2017.

Işık, N. (2006). Bulgur Yemekleri [Bulgur Dishes]. İstanbul: Alfa Basım.

Işılk, N. (2017). Interview with Osman Güldemir. Personal interview. Eskişehir, June 11, 2017.

Karadağ, M.G., Çelebi, F., Ertaş, Y., \& Şanlıer, N., (2014). Geleneksel Türk Mutfağından Seçmeler: Besin Ögeleri Açısından Değerlendirilmesi [Selections from Traditional Turkish Cuisine: Evaluation of Food Ingredients], Ankara: Detay Yayıncılık.

Key, J.T., Appleby, P.N., \& Rosell, M.S. (2006). Health effects of vegetarian and vegan diets. Proceedings of the Nutrition Society 65 (1): 35-41, doi: 10.1017/Soo29665115004334

Kiraz, M. (2007). Aydın İli Koçarlı İlçesi Mutfak Kültürü ve Yemekleri [Aydın, Koçarlı Cuisine]. Konya: Selçuk Üniversitesi, Aile Ekonomisi ve Beslenme Eğitimi Bilim Dalı.

Kühn, K. (2008). Meat-free restaurants underline veggie trend. Caterer \& Hotelkeeper 198 (4525): 10.

Matlovičová K., \& Husárová M. (2017). Heritage marketing a možnosti jeho využitia pri rozvoji turistickej destinácie: Prípadová štúdia hradu Čičva [Potential of the heritage marketing in tourist destinations development: Čičva castle ruins case study], Folia Geographica, Vol. 59, No 1, pp. 5-35.

Matlovičová K., Kolesárová J., \& Matlovič R. (2014). The use and stimulation of culinary tourism in learning about local and regional cultural peculiarities and historical heritage. In Faracik R., Widawski K. (Eds), 2014. Enhancing competitiveness of V4 historic cities to develop tourism. Aspects of cultural heritage." Krakow -Debrecen, 2014, Center-Print Kft, Debrecen. ISBN 978-615-5212-26-o, pp.: 141-164.

Mendes, E., (2013). An Application of the Transtheoretical Model to Becoming Vegan. Social Work in Public Health 28 (2): 142-149, doi: 10.1080/19371918.2011.561119.

Privitera, D., Nedelcu, A., \& Nicula, V., (2018). Gastronomic and food tourism as an economic local resource: Case studies from Romania and Italy. GeoJournal of Tourism and Geosites, Year XI, no. 1, vol. 21, p.143-157. ISSN 2065-0817, E-ISSN 2065-1198.

Radnitz, C., Beezhold, B., \& DiMatteo, J., (2015). Investigation of lifestyle choices of individuals following a vegan diet for health and ethical reasons. Appetite 90 (2015): 31-36, doi: 10.1016/j.appet.2015.02.026.

Rivera, M., \& Shani, A., (2013). Attitudes and orientation toward vegetarian food in the restaurant industry - An operator's perspective. International Journal of Contemporary Hospitality Management, 25 (7): 10491065, doi: 10.1108/IJCHM-07-2012-0116.

Şallı, G., (2017). Interview with Osman Güldemir. Personal interview. Eskişehir, July 5, 2017.

Sarıçay, N., (2017). Interview with Osman Güldemir. Personal interview. Eskişsehi.

Shani, A., \& DiPietro, R.B. (2007). Vegetarians: A Typology for Foodservice Menu Development. FIU Hospitality Review 25 (2): 66-73.

Stahler, C. (2012). How often do Americans eat vegetarian meals? And how many adults in the U.S. are vegetarian? http://www.vrg.org/blog/2012/05/18/how-often-do-americans-eat-vegetarian-meals-andhow-many-adults-in-the-u-s-are-vegetarian/

Tamkoç, G., (2000). Vejetaryen Türk Mutfağı [Vegetarian Turkish Cuisine]. Ankara: Kültür Bakanlığı Yayınları.

Tezcan, M., (1999). Etyemezlik-Vejetaryenlik Tercihinin Kültürel Boyutları [Cultural Dimensions of IrritabilityVegetarianism]. Ankara: Türk Mutfak Kültürü Üzerine Araştırma ve Tanıtma Vakfi Yayınları.

Son, T., Güzin Y., \& Bulut, M., (2016). Yaşam Tarzı Olarak Vegan ve Vejetaryenlik [Vegan and Vegetarianism as a Lifestyle]. International Journal of Human Sciences, 13 (1): 830-843, doi: 10.14687/ijhs.v13i1.3614.

Yıldız, E., (2017). Interview with Osman Güldemir. Personal interview. Eskişehir, June 15.

Yolal, M., (2016). Turizm Araştırmalarında Örnekleme - Bibliyometrik Bir Araştırma [Sampling in Tourism Research - A Bibliometric Research]. Ankara: Detay Yayıncılık.

Submitted:

09.08.2018
Revised:

20.11.2018
Accepted and published online 22.11.2018 